\title{
SYNTHESIS OF TWEEN-COATED SILVER NANOPARTICLES BY A PLASMA-CHEMICAL METHOD: CATALYTIC AND ANTIMICROBIAL ACTIVITIES
}

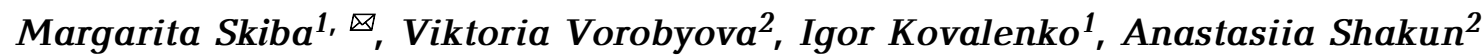

https://doi.org/10.23939/chcht14.03.297

\begin{abstract}
Stable silver nanoparticles were rapidly synthesized by simple, eco-friendly atmospheric pressure plasma method using non-ionic Tween 80 (polyoxyethylene-(80)-sorbitan monooleate) as capping agent. Influences of Tween 80 concentration on the formation efficiency of silver nanoparticle, their average size and stability have been studied. The synthesized silver nanoparticles had significant antibacterial activity on two strains of Gram bacteria. The AuNPs showed excellent catalytic activity for the reduction of $p$-nitrophenol (4-NP) to $p$-aminophenol (4-AP) in the presence of $\mathrm{NaBH}_{4}$.
\end{abstract}

Keywords: silver nanoparticles, plasma discharge, Tween 80, antibacterial, catalytic reduction, 4-nitrophenol.

\section{Introduction}

Silver nanoparticles (AgNPs) are amongst the most extensively studied nanomaterials, which fascinate scientists due to their promising applications in optoelectronics, sensing, catalysis, etc. AgNPs can be synthesized using different approaches, such as electrochemical methods, decomposition, microwave-assisted techniques, and wet chemical procedures [1]. However, the chemicals used in those methods are usually flammable and highly toxic, which limit their applications in many areas since they may pose risks to human health [2]. Therefore, there is an increasing need to promote a safe and environmentally friendly procedure to synthesize metallic nanoparticles without using toxic chemicals.

Recently, the development of effective plasma chemistry methods has received much attention as an alternative approach to synthesize metal nanoparticles, which can eliminate or minimize the generation of toxic or hazardous waste materials and establish a sustainable

\footnotetext{
${ }^{1}$ Ukrainian State University of Chemical Technology,

8, Gagarina Ave., 49005 Dnipro, Ukraine

${ }^{2}$ National Technical University of Ukraine "Igor Sikorsky Kyiv Polytechnic Institute",

37, Peremohy Ave., 03056 Kyiv, Ukraine

Margaritaskiba88@gmail.com

(c) Skiba M., Vorobyova V., Kovalenko I., Shakun A., 2020
}

process [3]. Atmospheric pressure plasma (APP) is new useful and simple preparation method of metal nanoparticles because this nonequilibrium plasma can provide rapid reactions due to the reactive chemical species [4]. Furthermore, in the case of APP method, high-energy radicals and a variety of reactive species are produced, thus resulting in direct synthesizing of various NPs, such as metals [3-6], alloys [7, 8], oxides [9-11], and composites $[12,13]$. Among plasma-chemical discharges, contact non-equilibrium low-temperature plasma (CNP) is a promising option from practical application standpoint [14]. By varying the composition of liquid phases, it is possible, in some degree, to manage the paths of chemical transformations and composition of obtained products [14]. Previously the efficiency of using the contact nonequilibrium low-temperature plasma in comparison with the conventional method of chemical reduction in solutions and photochemical deposition for synthesis of AgNPs was shown [15]. Therefore, this synthesis technique seems to have potential for metal nanoparticles synthesis. Many approaches have been tested for the preparation of highly stable silver nanoparticle dispersions, since the stabilization of nanoparticles is one of the key problems to applications. A number of chemicals can be used as protecting agents in the synthesis of AgNPs. The efficiency of CNP use for the synthesis of silver nanoparticles from the aqueous solutions of metal salts one-shot in the presence of sodium alginate, citrate, PVA is demonstrated in other published works [16-20]. However, it is known that the specific properties of the nanoparticles depend on the type of stabilizer (capping) agent. Therefore, studying of the process of obtaining silver nanoparticles in the presence of other type of stabilizing reagent, under the action of plasma discharge, is of scientific and practical interest. Actually, many nonionic surfactants can function as protecting agents to synthesize noble metal nanoparticles. Polyoxyethylene sorbitan monooleate, commercially known as Tween-80, is a popular non-ionic surfactant used widely in cosmetics, foods, pharmaceutical products, and in biochemical research [21].

It is commonly known and well established that silver nanoparticles show antibacterial activity. The 
antibacterial and antifungal properties of AgNPs mean that they are frequently present in air/water filters and many other consumer products [22]. In addition, AgNPs are well known as redox catalysts, and promote electron transfer through a separate pathway with relatively low activation energy [23]. The production of silver nanoparticles is especially important for their varied industrial catalytic applications.

This paper aims to propose a simple eco-friendly method for obtaining colloidal solutions of silver nanoparticles by using of contact non-equilibrium lowtemperature plasma with addition of polysorbate- 80 and to assess their antibacterial and catalytic activity.

\section{Experimental}

\subsection{Materials}

All the chemicals and reagents used in this study were of analytical grade. Silver nitrate (99.8\%, Kishida), Polysorbate 80 (Tween 80), 4-nitrophenol (4-NP), sodium borohydride $\left(\mathrm{NaBH}_{4}\right)$ were purchased from Merck Co. Ltd. (Darmstadt, Germany). Aqueous solutions of silver nitrate and $\mathrm{AlgNa}$ were prepared using ultrapure water (Direct-Q UV, Millipore) and were utilized as starting materials without further purification.

\subsection{Synthesis of Silver Nanoparticles AgNPs}

The nanosized silver colloids were prepared by a plasma chemical process in aqueous solution in the presence of Tween 80 as a stabilizing agent. Tween 80 coated silver nanoparticles were synthesized using synthesis reactor [18]. $\mathrm{AgNO}_{3}$ was dissolved in double distilled water to give a solution of $0.5 \mathrm{~g} / 1$. To $40 \mathrm{ml}$ silver nitrate solution $0.1-0.3 \mathrm{ml}$ Tween 80 solution was added. The resulting reaction mixture was treated in the reactor with the discharge of contact non-equilibrium lowtemperature plasma with fixed parameters (pressure, current strength, voltage). The parameters of plasma were $I=120 \mathrm{~mA}, P=0.08 \mathrm{MPa}$. The electrodes are directly connected to the lines in order to apply voltage from the power sources. After plasma irradiation treatment, the resultant colloidal solutions were naturally cooled from $303-308 \mathrm{~K}$ to room temperature. The final product was obtained as a colloidal dispersion. The change in color of a mixture of $\mathrm{AgNO}_{3}$ to brown indicates the synthesis of silver nanoparticles. UV-Vis spectrophotometer equipped with a $1 \mathrm{~cm}$ quartz cell was used for recording the visible spectra and absorbance measurements. The strong SPR band at $380-440 \mathrm{~nm}$ in UV-Vis spectra thus confirms the formation of silver nanoparticles. The AgNPs obtained by plasma discharges were centrifuged at $5000 \mathrm{rpm}$ for $5 \mathrm{~min}$. The dried powders were then used for further characterization.

\subsection{Characterization Techniques}

Spectra of colloidal solutions were obtained by means of spectrophotometer UV-5800PC using quartz cuvettes in the wavelength range of 190-700 nm (FRU, China). Zeta potential of colloidal solutions was measured by means of the analyzer of zeta potential and particle size Zetasizer Nano-25 (Malvern Instruments Ltd., Malvern, England). TEM micrograph of the sample was taken using the JEOL TEM (Model 100 CX II; Tokyo, Japan). Disperse phase of the solution obtained as a result of plasma-chemical treatment of the solution and dried in the air at $298 \mathrm{~K}$ was studied with the use of X-ray diffractometer Ultima IV Rigaku.

\subsection{Antibacterial Activity Measurements}

The measurement of colony-forming unit (CFU) method was used to study the antibacterial activity of the synthesized silver nanoparticles. Tween 80 -coated silver nanoparticles are content by weight in the spinning solution, which contains about $1.510^{5}$ colony-forming units (CFU) of $S$. aureus and E. coli, respectively. The mixtures were cultured at $310 \mathrm{~K}$ in a shaking incubator for $12 \mathrm{~h}$. Silver nitrate was also tested as blank control and positive control, respectively. $100 \mathrm{ml}$ of each of these cell solutions was seeded onto LB agar using a surface spread plate technique. The plates were incubated at $310 \mathrm{~K}$ for $24 \mathrm{~h}$. Then the numbers of bacterial colonies (CFU) were counted. The counts were used to calculate the surviving number of bacteria. Growth inhibition rate was calculated according to the following equation: GIR $=\{(\mathrm{CFU} / \mathrm{ml}$ of control medium $\mathrm{CFU} / \mathrm{ml}$ of silver nanoparticles solution treated medium $) /(\mathrm{CFU} / \mathrm{ml}$ of control medium $)\} 100$.

\subsection{Catalytic Activity}

As a model reaction, we selected the reduction of 4-NP to 4-AP by $\mathrm{NaBH}_{4}$. A standard catalytic test reaction was carried out in a quartz cuvette. The reaction process was as follows: $1.5 \mathrm{ml}$ of $0.15 \mathrm{mM} 4-\mathrm{NP}$ was mixed with $1.0 \mathrm{ml}$ of $0.02 \mathrm{M} \mathrm{NaBH}_{4}$ in the cell for UV-Vis measurements. Immediately, the colour change was observed from light yellow to deep yellow. $0.5 \mathrm{ml}$ of Tween-coated AgNPs solution was added to the above mixture. The intensity of the absorption peak at $400 \mathrm{~nm}$ in the UV-Vis spectrophotometer was used to monitor the process of the conversion of $p$-nitrophenol $(p-\mathrm{NP})$ to $p$-aminophenol ( $p$-AP).

\section{Results and Discussion}

The polysorbates are amphipathic, nonionic surfactants composed of fatty acid esters of polyoxyethylene sorbitan. The structure of Tween 80 is shown in Fig. 1. 
<smiles>CCCCCCCCCCCC(=O)OCCOC(C)C(C)(OCCC(C)(C)O)C1OCC(C)(OCCC(C)(C)O)C1(C)OCCCN</smiles>

Fig. 1. Chemical structure of polysorbates $80(w+x+y+z$ refers to the total number of oxyethylene subunits on each surfactant molecule and may not exceed 20)

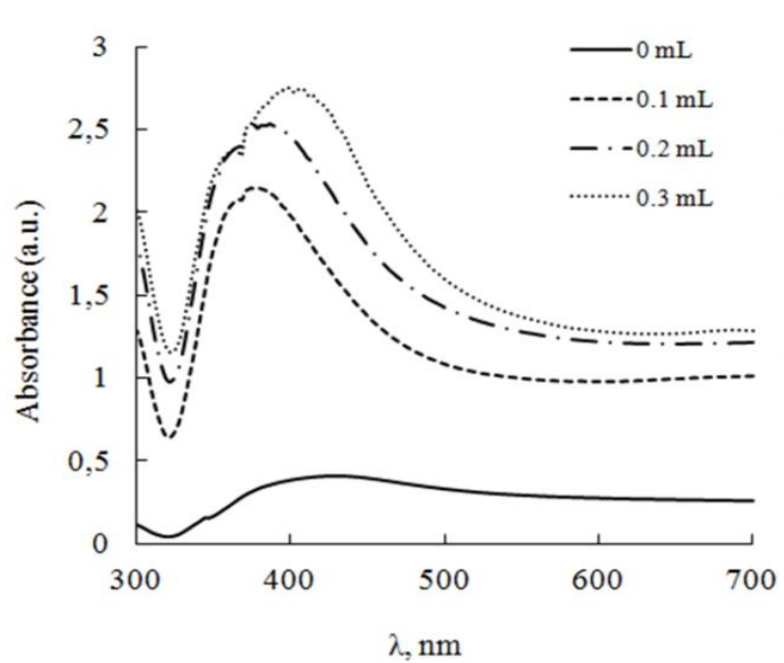

a)

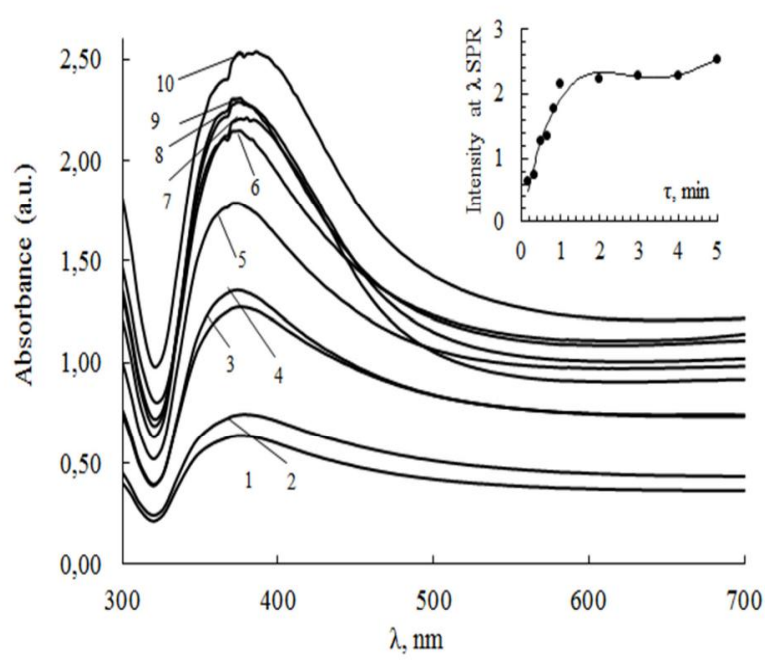

c)

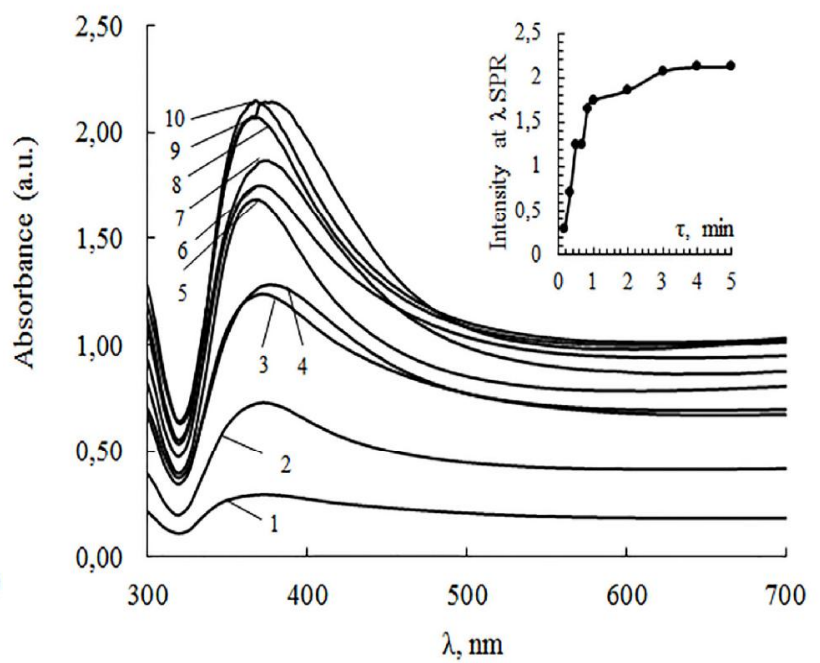

b)

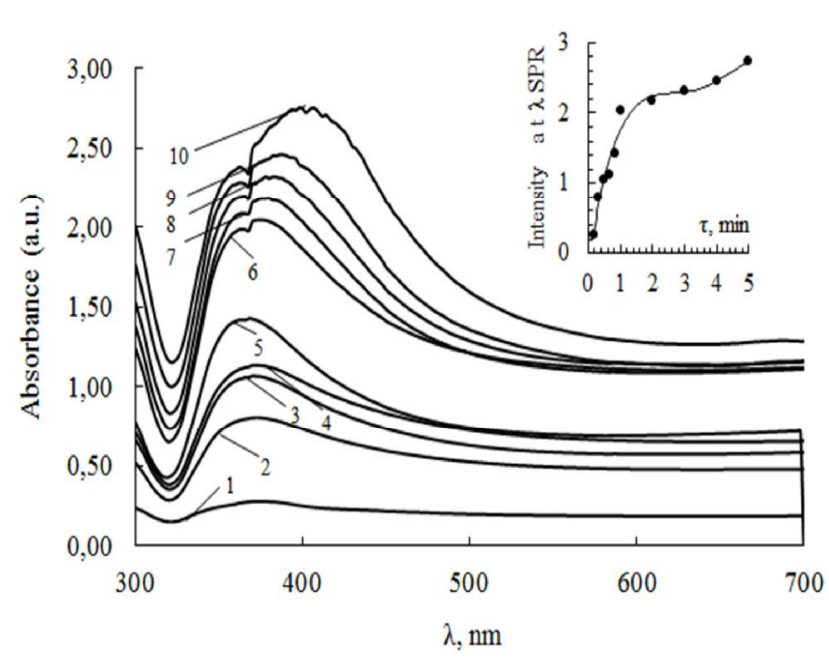

d)

Fig. 2. The UV-Vis absorption spectrum of silver nanoparticles/Tween 80 prepared by discharge plasma at various concentrations of Tween 80 (a), UV-Vis spectra of aqueous solution $\mathrm{AgNO}_{3}$ /Tween 80 treated with plasma at different discharge durations, for various concentrations of Tween $80: 0.1 \mathrm{ml}(\mathrm{b}) ; 0.2 \mathrm{ml}$ (c) and $0.3 \mathrm{ml}(\mathrm{d})$

$1-10 \mathrm{~s} ; 2-20 \mathrm{~s} ; 3-30 \mathrm{~s} ; 4-40 \mathrm{~s} ; 5-50 \mathrm{~s} ; 6-1 \mathrm{~min} ; 7-2 \mathrm{~min} ; 8-3 \mathrm{~min} ; 9-4 \mathrm{~min} ; 10-5 \mathrm{~min}$. 
Influence of Polysorbate 80 (Tween 80) on the formation efficiency of silver nanoparticle solutions was followed by UV-Vis absorption measurements. Fig. 2a shows UV-Vis spectra of colloidal solutions obtained in the CNP plasma-irradiated $\mathrm{AgNO}_{3}$ without and at varying concentration of Tween 80 at the fixed silver nitrate concentration of $0.5 \mathrm{~g} / \mathrm{l}$ and plasma irradiation for $5 \mathrm{~min}$. Analysis of obtained data showed that the nanoparticles are formed without using Tween 80 as a result of plasma discharge action on the solution of silver nitrate. Colloidal solutions of silver are characterized by the presence of the maximum of absorption SPR $\left(\lambda_{\max }\right)$ at $424 \mathrm{~nm}$. When different amount $(0.1-0.3 \mathrm{ml})$ of Tween is introduced into the reaction mixture before its treatment with $\mathrm{CNP}$, a blue shift is observed in the $\lambda_{\max }$ of the plasmon band from 424 to $380-402 \mathrm{~nm}$ along with increase in intensity. The increase in intensity of UV absorption spectra indicates increase in a number of silver nanoparticles with increasing concentration of Tween [24].

The synthesis was also monitored by various time intervals of the reaction medium treatment with plasma discharge. Figs. 2b, c show the UV-Vis spectra of the AgNPs and various volume of Tween 80 obtained after different irradiation times. The data in Fig. 2 reveal several important findings which can be presented as follows:

(i) for all samples at the early stage reaction duration $(<20 \mathrm{~s})$, the plasmon band is broad and weak indicating low conversion of $\mathrm{Ag}^{+}$to $\mathrm{AgNPs}$ at this irradiation duration;

(ii) with further increase in the irradiation time to $1-5 \mathrm{~min}$ there is a gradual increase in the absorption intensity and without little red shift in the peak wavelength, which indicates that the AgNPs content increases with increased irradiation time and the mean diameter of the AgNPs does not change much;

(iii) after 5 min treatment the strongest SPR band occurs at $382 \mathrm{~nm}(0.1 \mathrm{ml}$ Tween 80$), 382 \mathrm{~nm}(0.2 \mathrm{ml}$ Tween 80$)$, and $400 \mathrm{~nm}(0.3 \mathrm{ml}$ Tween 80$)$ implying that large amounts of silver ions are reduced and used for silver particles formation;

(iv) as can be seen from absorption intensity SPR, the particle size continue to get smaller by changing the concentrations of Tween 80 from 0.1 to $0.3 \mathrm{ml}$; with the increase of the concentrations of Tween 80 from 0.1 to $0.3 \mathrm{ml}$ the expansion and bifurcation of the peak of the UV spectrum is observed, which indicates the formation of nanoparticles of silver with more size distribution.

Zeta potential values reveal details about the stability and surface charge of the synthesized AgNPs. Particles with highly negative or positive surface charge are considered to be stable. At initial concentration of $\mathrm{Ag}^{+}$in solution without stabilizer, there was little variation in the zeta potential value of AgNPs, indicating low stability of the synthesized nanoparticles (Table 1).

Table 1

Size and zeta potential of silver nanoparticles prepared in plasma treatment conditions

\begin{tabular}{|c|c|c|}
\hline Tween 80, ml & Average size of AgNPs, $\mathrm{nm}$ & Zeta potential, $\mathrm{mV}$ \\
\hline- & 60.1 & -14.2 \\
\hline 0.1 & 41.3 & -23.5 \\
\hline 0.2 & 38.0 & -27.1 \\
\hline 0.3 & 37.4 & -26.6 \\
\hline
\end{tabular}

Overall, all obtained samples solutions of silver nanoparticles/Tween 80 depending on the initial concentration of stabilizer, are characterized by the average value of zeta potential in the range from -23.5 to $-26.6 \mathrm{mV}$ (Table 1 ), which is a general indication that the colloidal solution is highly stable. The data obtained (Table 1) indicate that the average diameter of the nanoparticles formed under plasma discharge impact is $41.3-37.4 \mathrm{~nm}$ and does not significantly increase with increasing initial concentration of Tween 80 . The size of the particles actually formed in the aqueous solution under plasma discharge conditions was determined. To do this, the study of particle size distribution was performed, and the average particle size of plasmochemically prepared silver dispersions at different initial concentrations of Tween was determined.

The SEM image of the prepared Ag/Tween (same sample (Tween 80$)=0.2 \mathrm{ml}, \tau=5 \mathrm{~min}$ ) is shown in
Fig. 3. As a result of the plasma chemical impact, spherical silver nanoparticles are formed.

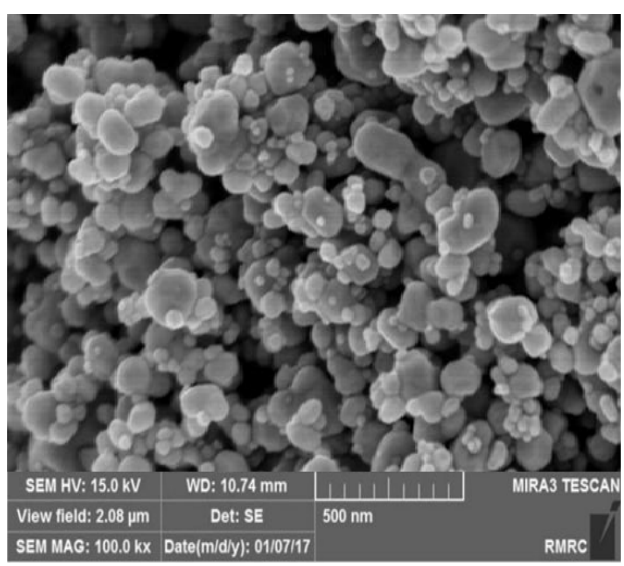

Fig. 3. The SEM image of the prepared $\mathrm{Ag} /$ Tween $(($ Tween 80$)=0.2 \mathrm{ml}, \tau=5 \mathrm{~min})$ 
Nitrophenol is one of the water pollutants having high toxicity and is of great environmental concern. Due to electron withdrawing nitrogroup in 4-NP it is resistant to chemical, biological oxidation and hydrolysis. The catalytic activities of AgNP catalysts were investigated using the reduction of $p$ $\mathrm{NP}$ to $p$-AP in the presence of $\mathrm{NaBH}_{4}$ as a model reaction (Scheme 1).

The kinetics of the reaction was spectrophotometrically studied and presented in Fig. 4.

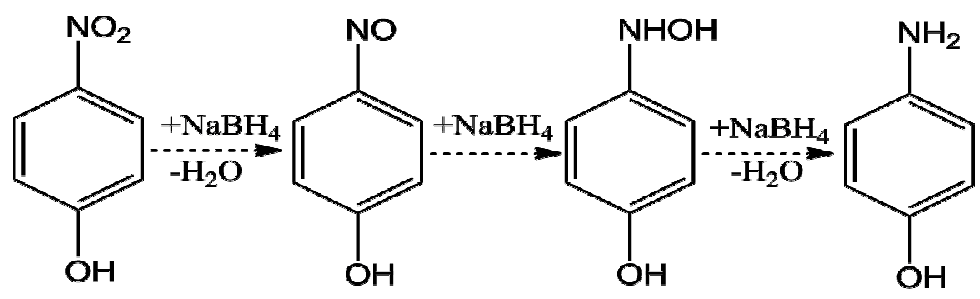

Scheme 1. Representation of the overall reaction process for converting $p$-NP top-AP by $\mathrm{NaBH}_{4}$ in the presence of $\mathrm{Ag} \mathrm{NPs}$ as the catalyst

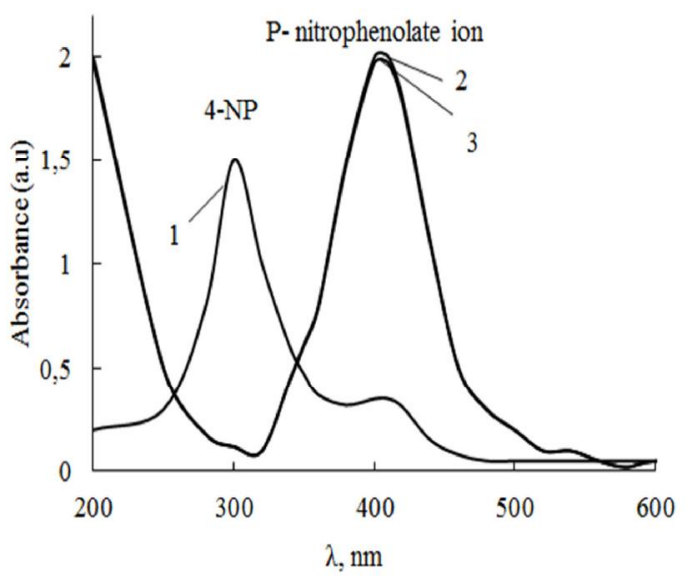

a)

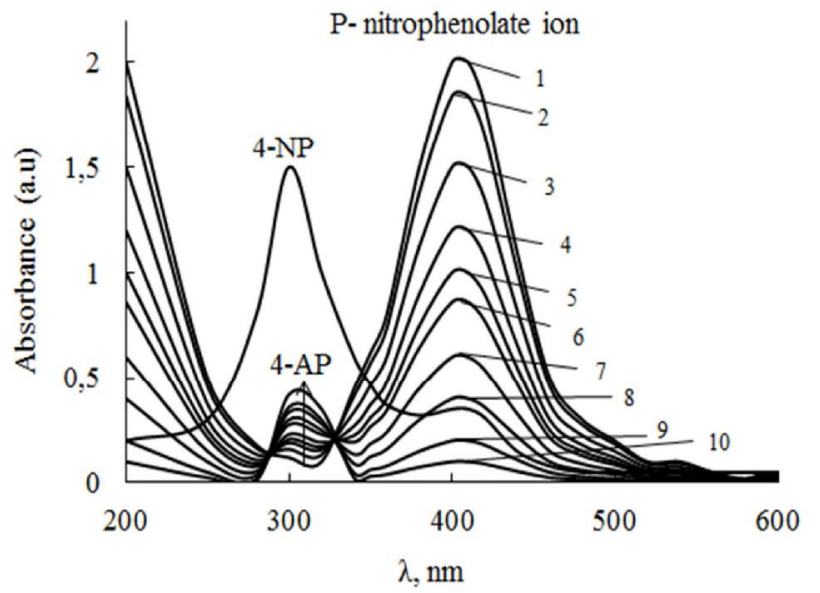

b)

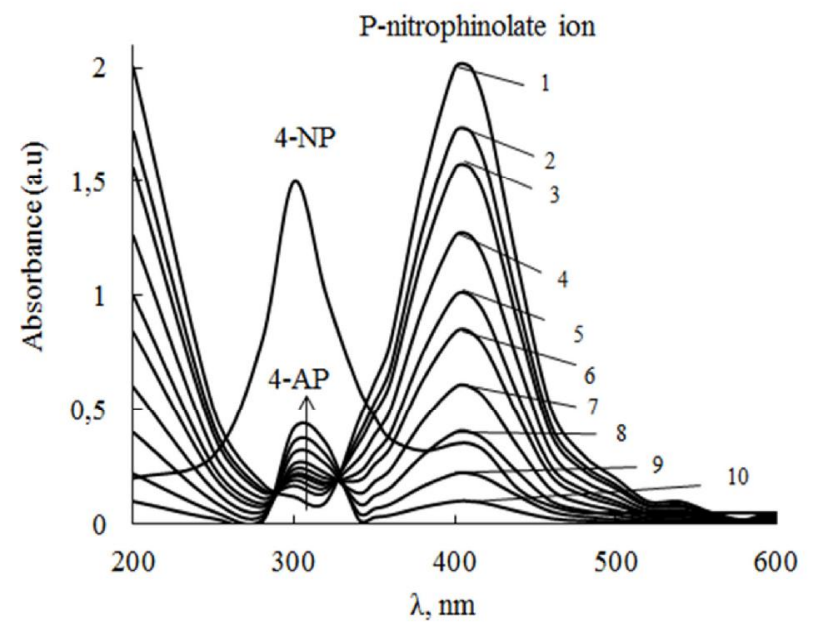

c)

Fig. 4. UV-Vis absorption spectra of $p$-nitrophenol and $\mathrm{NaBH}_{4}$ versus time of the blank sample (without Tween 80-AgNPs catalyst) (a) and in the presence of Tween 80-AgNPs $(0.2 \mathrm{ml}$ Tween 80$)$ (b) and Tween 80-AgNPs (0.3 ml Tween 80) (c) catalyst). 1-0 min; 2 - $2 \mathrm{~min} ; 3-4 \mathrm{~min} ; 4-6 \mathrm{~min} ; 5-8 \mathrm{~min} ; 6-10 \mathrm{~min} ; 7-12 \mathrm{~min} ; 8-14 \mathrm{~min} ; 9-16 \mathrm{~min} ; 10-18 \mathrm{~min}$ 
Growth inhibition rates of silver nanoparticles/Tween 80

\begin{tabular}{|c|c|c|c|c|}
\hline \multirow{2}{*}{ Tested bacterial strains } & \multicolumn{3}{|c|}{ Growth inhibition rate, $\%$} \\
\cline { 2 - 5 } & \multirow{2}{*}{ Blank } & \multicolumn{3}{|c|}{$\operatorname{Ag}^{0}(0.5 \mathrm{~g} / \mathrm{l})$} \\
\cline { 3 - 5 } & & 0.1 & 0.2 & 91 \\
\hline Escherichia coli & 0 & 86 & 91 & 91 \\
\hline Staphylococcus aureus & 0 & 91 & 93 & 92 \\
\hline
\end{tabular}

A strong absorbance peak was found for $p$-NP at $317 \mathrm{~nm}$, that shifted to $400 \mathrm{~nm}$ in the presence of $\mathrm{NaBH}_{4}$ due to the deprotonation of 4-NP (pKa of 4-NP = 7.16). After adding $\mathrm{NaBH}_{4}$ into the aqueous solution of $p$-NP, the colour of the solution also changed from light yellow to intense yellow due to the formation of $p$-nitrophenolate ion. However, no reduction was observed, even after the period of 1-3 days in the presence of $\mathrm{NaBH}_{4}$ (Fig. 4a). Metal nanoparticles, such as silver are known to expedite electron transfer from donors (in this case $\mathrm{BH}_{4}{ }^{-}$) to acceptors (in this case $p$-NP) [25]. After the addition of AgNPs as a catalyst, the reduction of 4-NP started immediately, and the colour of the reaction solution became lighter. The progress of the reaction was monitored by UV-Vis absorbance spectroscopy and visually by the disappearance of the yellow colour of $p$-NP. Addition of AgNPs to the reaction medium accounted for the rapid decline in the absorption intensity at $400 \mathrm{~nm}$ simultaneously accompanied by the appearance of a relatively wider band at $298 \mathrm{~nm}$ indicating the formation of 4-AP (Figs. 4b, c). Moreover, a single point of intersection could be observed in the UV-Vis spectra, where all the spectra intersect. This indicates that in the catalytic reduction the conversion of 4-NP gives only one product of 4-AP. Within $18 \mathrm{~min}$ of the reaction duration, 4-NP was completely reduced to 4-AP which indicates conversion of 4-NP as depicted in Fig. 4.

It should also be noted that the AgNPs formed with the addition of $0.3 \mathrm{ml}$ stabilizer exhibit greater catalytic activity. Most likely, such an effect is due to the presence of a greater number of formed AgNPs. The evidence of this fact is also the preliminary data. Thus, Figs. 2c, d shows that the intensive of absorption at addition of $0.3 \mathrm{ml}$ of the stabilizer is higher compared to $0.2 \mathrm{ml}$, which indicates an increase in the concentration of the formed nanoparticles. This illustrates the high speed of the Ag NPs catalytic activity and its high selectivity for $p$-AP yield.

Silver has always been used against various diseases; in the past it found use as an antiseptic and antimicrobial against gram-positive and gram-negative bacteria due to its low cytotoxicity [26]. The quantitative characterization of the antibacterial activity of the synthesized nanoparticles is appropriate. The plasmachemically synthesized AgNPs were studied for their antibacterial activity. The values were reported in term of inhibition levels percentage (\%) Table 2.

The anti-bacterial efficacies (ABE) of the $\mathrm{Ag}^{0} /$ Tween 80 solutions against $S$. aureus and E. coli are shown in Table 2, and the table data indicate that the $\mathrm{Ag} /$ Tween $80(0.2 \mathrm{ml})$ solution has higher anti-bacterial efficacies and this activity is quite strong. The ABE against $E$. coli is lower than that against $S$. aureus, probably because of the difference in cell walls between gram-positive and gram-negative bacteria. The cell wall of E. coli, which consists of lipids, proteins and lipopolysaccharides (LPS), provides effective protection against biocides. However, the cell wall of gram-positive bacteria, such as S. aureus, does not consist of LPS [26].

\section{Conclusions}

A simple one-step green approach was developed for the synthesis of silver nanoparticles using contact nonequilibrium low-temperature plasma and polysorbate 80 (Tween 80) as capping agent. The formation of silver colloidal solutions in the presence of capping agent is characterized by the presence of peak $\lambda_{\max }=380-402 \mathrm{~nm}$ in the spectra. According to the results of our findings, introduction of stabilizer promotes the stability of silver nanoparticles. The content of nanoparticles grows with the increase of duration of plasma action on the solution; processing during 4-5 min provides formation of silver nanoparticles. The average size of formed silver particles is up to $50 \mathrm{~nm}$. The synthesized silver nanoparticles had significant antibacterial activity on Escherichia coli and Staphylococcus aureus. The silver nanoparticles that are formed are highly stable and have significant catalytic activity toward reduction of 4-nitrophenol to 4-aminophenol.

\section{References}

[1] Zhang X., Liu Z., Shen W., Gurunathan S.: Int. J. Mol. Sci., 2016, 17, 1534. https://doi.org/10.3390/ijms 17091534

[2] Abdelghany T., Al-Rajhi A., Al Abboud M. et al.: BioNanoSci. 2017, 8, 5. https://doi.org/10.1007/s12668-017-0413-3

[3] Saito G., Akiyama T.: J. Nanomater., 2015, 16, 1. https://doi.org/10.1155/2015/123696 
[4] Mariotti D., Sankaran R.: J. Phys. D Appl. Phys., 2010, 43, 323001. https://doi.org/10.1088/0022-3727/43/32/323001 [5] Jin S., Kim S., Lee S., Kim J.: J. Nanosci. Nanotechnol., 2014, 14, 8094. https://doi.org/10.1166/jnn.2014.9428

[6] Hofft O., Endres F.: Phys. Chem. Chem. Phys., 2011, 13, 13472. https://doi.org/10.1039/C1CP20501C

[7] Lee S.-J., Lee H., Jeon K.-J. et al.: Nanoscale Res. Lett, 2016, 11, 344. https://doi.org/10.1186/s11671-016-1557-8

[8] Saito G., Akiyama T.: J. Nanomater., 2015, 16, 1. https://doi.org/10.1155/2015/123696

[9] Kelgenbaeva Z., Omurzak E., Thara H. et al.: Phys. Status Solidi A, 2015, 212, 2951. https://doi.org/10.1002/pssa.201532502

[10] Nakasugi Y., Saito G., Yamashita T., Akiyama T.: J. Appl. Phys., 2014, 115, 123303. https://doi.org/10.1063/1.4869126

[11] Sabzehparvar M., Kiani F., Tabrizi N.: Mater. Today: Proceed., 2018, 5, 15821. https://doi.org/10.1016/j.matpr.2018.05.080

[12] Lin L., Starostin S., Hessel V., Wang Q.: Chem. Eng. Sci., 2017, 168, 360. https://doi.org/10.1016/j.ces.2017.05.008

「13] Hu Y., Li L., Zhang L., Lv Y.: Sensor. Actuat. B-Chem., 2017, 239, 1177. https://doi.org/10.1016/j.snb.2016.08.082

$\lceil 14\rceil$ Pivovarov A., Kravchenko A., Tishchenko A. et al.: Russ. J. Gen. Chem., 2015, 85, 1339.

https://doi.org/10.1134/s1070363215050497.

[15] Skiba M., Pivovarov A., Makarova A. et al.: East.-Eur. J. Enterprise Technol., 2017, 6, 59. https://doi.org/10.15587/17294061.2017.118914

[16] Pivovarov O., Skiba M., Makarova A. et al.: Vopr. Khim. Khim. Tekhnol., 2017, 6, 82.

[17] Skiba M., Pivovarov A., Makarova A., Vorobyova V.: East.Eur. J. Enterprise Technol., 2018, 2, 4.

https://doi.org/10.15587/1729-4061.2018.127103

[18] Skiba M., Pivovarov A., Makarova A. et al.: Chem. J. Moldova, 2018, 13, 7. https://doi.org/10.19261cjm.2018.475

[19] Skiba M., Pivovarov O., Makarova A., Parkhomenko V.: Vopr. Khim. Khim. Tekhnol., 2018, 3, 113.

[20] Skiba M., Vorobyova V., Pivovarov O. et al.: East.-Eur. J. Enterprise Technol., 2018, 5-6 . 51. https://doi.org/10.15587/17294061.2018.144602
[21] Li H., Zhang A., Hu Y. et al.: Nanoscale Res. Lett., 2012, 7, 612. https://doi.org/10.1186/1556-276X-7-612

[22] Le Ouay B., Stellacci F.: Nano Today, 2015, 10, 339. https://doi.org/10.1016/j.colsurfb.2018.06.027

[23] Singha J., Mehta A., Rawata M., Basu S.: J. Environ. Chem. Eng., 2018, 6, 1468. https://doi.org/10.1016/j.jece.2018.01.054

[24] Joseph D., Lee H., Huh Y., Han Y.: Mater. Design, 2018, 160, 169. https://doi.org/10.1016/j.matdes.2018.09.003

[25] Gangula A., Podila R., Karanam L. et al.: Langmuir, 2011, 27, 15268. https://doi.org/10.1021/la2034559

[26] Sondi I., Salopek-Sondi B.: J. Colloid Interf. Sci., 2004, 275,

177. https://doi.org/10.1016/i.jcis.2004.02.012

[27] Feng Q., Wu J., Chen G. et al.: J. Biomed. Mater. Res., 2000, 52, 662. https://doi.org/10.1002/1097-

4636(20001215)52:4<662::AID-JBM10>3.0.CO;2-3

Received: November 09, 2018 / Revised: December 04, 2018 / Accepted: June 23, 2019

\section{ОДЕРЖАННЯ НАНОЧАСТИНОК СРІБЛА СТАБІЛІЗОВАНИХ ТВІНОМ ПЛАЗМОХІМІЧНИМ СПОСОБОМ: КАТАЛІТИЧНІ ТА АНТИМІКРОБНІ ВЛАСТИВОСТІ}

Анотація. Стабільні наночастинки срібла було синтезовано простим, екологічно чистим, плазмохімічним методом 3 використанням нейонногенного Твін-80 (поліоксіетилен-(80)сорбітан моноолеат) як стабілізуючого агента. Досліджено вилив конщентрації Твін 80 на ефективність формування наночастинок срібла, їх середній розмір і стабільність. Синтезовані наночастинки срібла проявляють антибактеріальну активність на двох штамах бактерій. Наночастинки срібла показали високу каталітичну активність щчодо відновлення n-нітрофенолу (4-HФ) до амінофенолу (4-AФ) у присутності $\mathrm{NaBH}_{4}$.

Ключові слова: наночастинки срібла, плазмовий розряд, Твін-80, антибактеріальна дія, каталітичне відновлення, 4-нітрофенол. 